\title{
APLIKASI PEMBELAJARAN BAHASA JAWA BERBASIS ANDROID
}

\author{
Bramita Damayani Indiana ${ }^{1}$, Irfan Ramadhani ${ }^{2}$ \\ Dispendik \& Sekolah Tinggi Teknologi Cahaya Surya Kediri \\ bramitadamayani@gmail.com, 2irfanramadhani1994@gmail.com
}

\begin{abstract}
ABSTRAK
Aplikasi Bahasa Jawa merupakan hasil dari memanfaatkan perkembangan teknologi yang betujuan untuk menarik minat masyarakat dan pelajar dalam mempelajari dan melestarikan Bahasa Jawa. Aplikasi Pembelajaran Bahasa Jawa Berbasis Android merupakan aplikasi yang membantu dalam hal pembelajaran bahasa jawa dan pencarian arti kata dalam tingkatan bahasa krama bentuk mobile device. Aplikasi Pembelajaran Bahasa Jawa Berbasis Android dibuat dengan bahasa pemrograman Android dan database pendukungnya menggunakan sqlite. Tools yang digunakan dalam pembuatan aplikasi ini menggunakan eclipse. Aplikasi ini merupakan aplikasi yang dapat dipakai oleh semua pengguna Android secara umum yang ingin mempelajari tentang bahasa jawa atau yang ingin menterjemahkan bahasa Indonesia ke bahasa jawa atau sebaliknya. Aplikasi ini juga dapat mengetahui kemampuan pelajar maupun masyarakat dalam pembelajaran Bahasa Jawa dengan menggunakan fitur yang ada dalam aplikasi. Fitur yang terdapat pada aplikasi dapat melihat data kata-kata dalam tingkatan bahasa krama, melihat data kalimat dalam pribahasa jawa beserta artinya, menjawab soal yang telah ada dan dapat menyimpan nilai ataupun nama pengguna yang mengunakan, dan yang terakhir dapat mencari arti kata dalam kamus dan juga dapat menterjemahkan kalimat dalam tiga tingkat bahasa krama.
\end{abstract}

Kata Kunci: Android, Bahasa Jawa, Sqlite, Eclipse, Pembelajaran 


\begin{abstract}
The Javanese Language application is the result of utilizing technological developments that aim to attract the interest of the community and pupils/students in learning and preserving Javanese Language. Javanese Language Learning Application Based on Android is an application that helps Javanese language learning and the search for meaning of words in the level of Krama language in the form of mobile devices. Java Language Learning Application Based on Android is carried out using Android programming language and its supporting database using sqlite. Tools used in making this application using Eclipse. This application is an application that can be used by all Android users in general who want to learn about Javanese language or who want to translate Indonesian into Javanese or vice-versa. This application can also find out the ability of pupils/students and communities in learning Javanese Language by using the features in the application. The application features can see the words' used in the language level, see sentence data in Javanese proverbs along with their meanings, answer existing questions and can store values or usernames that use them, and the latter can search for meaning of words in the dictionary and can also translate sentences in three levels of manners.
\end{abstract}

Keywords: Android, Javanese, Sqlite, Eclipse, Learning 


\section{LATAR BELAKANG}

Bahasa Jawa merupakan salah satu kekayaan bahasa yang ada di Indonesia dan merupakan bahasa yang saat ini perlu dilestarikan. Bahasa Jawa merupakan salah satu mata pelajaran yang di berikan pada Sekolah Dasar (SD), Sekolah Menengah Pertama (SMP), dan Sekolah Menengah Atas (SMA) yang ada di daerah Jawa Timur maupun Jawa Tengah. Terapi minimnya sumber-sumber pustaka yang ada saat ini menjadi hambatan bagi para masyarakat dan pelajar untuk tertarik belajar dan melestarikan Bahasa Jawa. Perkembangan teknologi yang sangat pesat terutama di bidang teknologi informasi harus dapat di manfaatkan dengan baik dan benar. Salah satu teknologi yang berkembang saat ini merupakan perkembangan dibidang mobilitas yaitu Handphone. Berbagai fitur telah ditanamkan, hal ini tak lepas dari Sistem Operasi yang ditanamkan. Android merupakan Sistem Operasi yang digunakan pada perangkat mobile. Hingga saat ini Android terus berkembang baik dalam sistem maupun aplikasi.

Memanfaatkan perkembangan teknologi yang betujuan untuk menarik minat masyarakat dan pelajar dalam mempelajari dan melestarikan Bahasa Jawa. Diperlukan sebuah aplikasi yang dapat mempermudah masyarakat dan pelajar dalam pencarian data Bahasa Jawa dalam bentuk mobile device. Dengan desain yang lebih menarik diharapkan akan banyak masyarakat dan pelajar yang akan mempelajari kembali Bahasa Jawa dan memudahkan pelajar dalam belajar. Untuk itu aplikasi pembelajaran bahasa jawa berbasis Android ini dibuat sebagai pencarian data. Dengan Adanya aplikasi pembelajaran bahasa jawa berbasis Android ini diharapkan bisa memotivasi masyarakat dan pelajar untuk mau mempelajari atau memelihara Bahasa Jawa.

Berdasarkan pada latar belakang diatas, maka penulis perlu untuk melakukan suatu penelitian dengan menetapkan judul "APLIKASI PEMBELAJARAN BAHASA JAWA BERBASIS ANDROID“. Rumusan masalah yang dapat diidentifikasi dari latar belakang bagaimana membuat suatu aplikasi yang dapat membantu masyarakat dan pelajar dalam pembelajaran bahasa jawa berbasis Android. Bagaimana membuat suatu aplikasi yang dapat mengetahui pengetahuan masyarakat dan pelajar dalam pembelajaran bahasa jawa. 


\section{DASAR TEORI}

Penelitian diharapkan dapat berguna secara akademis maupun praktis, sehingga dapat bermanfaat untuk semua pihak. Adapaun tujuan dari penelitian ini untuk merancang dan membuat aplikasi pembelajaran bahasa jawa yang dapat membantu masyarakat dan pelajar dalam pembelajaran bahasa jawa berbasis Android. Membuat dan merancang aplikasi pembelajaran bahasa jawa yang dapat digunakan untuk mengetahui pengetahuan masyarakat dan pelajar dalam pembelajaran bahasa jawa dengan menggunakan fitur soal pada aplikasi. Bahasa Jawa merupakan bahasa yang digunakan penduduk suku bangsa Jawa di Jawa Tengah, Yogyakarta \& Jawa Timur. Selain itu, Bahasa Jawa juga digunakan oleh penduduk yang tinggal beberapa daerah lain seperti di Banten terutama kota Serang, kabupaten Serang, kota Cilegon dan kabupaten Tangerang, Jawa Barat khususnya kawasan Pantai utara terbentang dari pesisir utara Karawang, Subang, Indramayu, kota Cirebon dan kabupaten Cirebon.

Krama merupakan salah satu tingkatan bahasa dalam Bahasa Jawa. Bahasa ini paling umum dipakai di kalangan orang Jawa. Pemakaiannya sangat baik untuk berbicara dengan orang yang dihormati atau orang yang lebih tua. Yang dimaksud dengan ragam krama adalah bentuk unggah-ungguh bahasa Jawa yang berintikan leksikon krama, atau yang menjadi unsur inti di dalam ragam krama adalah leksikon krama bukan leksikon yang lain. Afiks yang muncul dalam ragam ini pun semuanya berbentuk krama (misalnya, afiks dipun-, -ipun, dan -aken). Ragam krama digunakan oleh mereka yang belum akrab dan oleh mereka yang merasa dirinya lebih rendah status sosialnya daripada lawan bicara. Ragam krama mempunyai tiga bentuk varian, yaitu krama lugu, karma andhap dan krama alus. Pada aplikasi bahasa jawa digunakan sebagai materi yang terdapat pada aplikasi. Bahasa Jawa digunakan sebagai acuan materi pada Bahasa Krama, Pribahasa, Soal dan Kamus yang terdapat pada aplikasi. Bahasa Jawa merupakan materi utama yang dibutuhkan pada aplikasi. Sedang Android merupakan sistem operasi berbasis Linux yang dirancang untuk perangkat seluler layar sentuh seperti telepon pintar dan komputer tablet. Android awalnya dikembangkan oleh Android, Inc., dengan dukungan finansial dari Google, yang kemudian membelinya pada tahun 2005. Sistem operasi ini dirilis secara resmi pada tahun 2007, bersamaan dengan didirikannya Open Handset Alliance, konsorsium dari perusahaan-perusahaan perangkat keras, perangkat lunak, dan telekomunikasi yang bertujuan untuk memajukan 
standar terbuka perangkat seluler. Priyanta F. (2011) menjelaskan aplikasi Android dibangun dengan bahasa pemrograman Java, artinya Android bukan merupakan bahasa pemrograman akan tetapi hanya menyediakan "lingkungan hidup" atau runtime environtment saja. Jadi runtime environtment pada Android yang disebut Davlik Virtual Machine merupakan Java Runtime Environtment (JRE) yang telah dioptimasi untuk device dengan sistem memori yang kecil. Akan tetapi untuk membuat aplikasi Android tetap membutuhkan JDK. Secara singkat, ada 3 hal yang harus dipersiapkan untuk dapat membuat aplikasi Android yaitu : Java Development Kit (JDK), Software Development Kit (SDK) dan IDE Android. IDE yang disarankan oleh Google adalah IDE eclipse.

Pada aplikasi Android merupakan sistem operasi yang akan digunakan untuk menjalankan aplikasi setelah aplikasi di buat. Sedang menurut Hermawan (2011) SQLite merupakan interface yang ada pada sistem operasi Android yang digunakan untuk membuat relasional database. SQLite menyokong implementasi dari SQL yang kaya untuk apapun yang dibutuhkan oleh aplikasi mobile. Setiap aplikasi dapat memiliki databasenya sendiri dengan pengaturan lengkap. Dengan penggunakan SQLite, dapat dibuat database untuk aplikasi yang digunakan untuk menyimpan dan mengatur data aplikasi terstruktur. SQLite merupakan mesin database SQL yang embedded atau tertanam. Tidak seperti kebanyakan database SQL lainnya, SQLite tidak memiliki proses server yang terpisah. SQLite membaca dan menulis secara langsung ke file disk biasa. Sebuah database SQL lengkap dengan berbagai tabel, indeks, indices, triggers, dan views, yang terkandung dalam sebuah file disk tunggal. Format file database adalah cross-platform yang artinya database dapat dengan bebas disalin antara 32-bit dan 64 -bit atau antara arsitektur big-endian dan little-endian (urutan byte). Fiturfitur ini membuat SQLite menjadi pilihan populer sebagai Format file Application . Dengan semua fitur diaktifkan, ukuran library bisa kurang dari 500KiB, tergantung pada platform target dan pengaturan optimasi compiler. Jika beberapa fitur opsional dihilangkan, ukuran library SQLite dapat dikurangi di bawah 300KiB.

Pada pembuatan aplikasi sqlite merupakan database yang digunakan untuk menyimpan data. Sqlite digunakan untuk menyimpan semua data krama, pribahasa, soal dan jawaban maupun skor dari pengguna. 


\section{METODE PENELITIAN}

Pada penelitian ini peneliti menggunakan kwalitatif research dengan cara descriptive untuk menggambarkan tentang analisa dan perancangan sistem applikasi ini.

\subsection{Analisis Dan Rancangan Sistem}

Analisa ini berdasarkan pada aplikasi yang sudah ada sebelumnya. Aplikasi pembelajaran bahasa jawa yang telah ada masih secara manual dalam bentuk buku. Hal ini kurang efisien dalam pencarian kata bahasa jawa dan kurang menarik bagi pelajar untuk mempelajari bahasa jawa, sehingga diperlukan sebuah aplikasi pembelajaran bahasa jawa yang baru untuk mengatasi permasalahan tersebut. Untuk itu diperlukan beberapa analisa seperti analisa data, analisa kebutuhan sistem dan spesifikasi program untuk mengetahui kebutuhan aplikasi yang akan dibangun, serta akan dilakukan pembahasan untuk mengetahui kekurangan dari aplikasi yang akan dibangun.

\subsubsection{Analisis Data}

Bahasa Jawa merupakan keanekaragaman budaya bahasa yang ada di Indonesia. Bahasa Jawa merupakan mata pelajaran yang ada di sekolah khususnya sekolah yang ada di Jawa Tengah, Jawa Timur dan DIY. Pada saat sekarang pustaka mengenai bahasa jawa sangat minim, buku pustaka bahasa jawa yang ada saat ini adalah Pepak Bahasa Jawa. Dengan minimnya pustaka yang ada dapat banyak masyarakat yang tidak mengerti tentang kata-kata dalam bahasa jawa. Masyarakat tidak tertarik dalam mempelajari bahasa jawa karena masyarakat saat ini lebih malas untuk membaca buku. Sedangkan pustaka saat ini yang adalah hanyalah dari buku pepak bahasa jawa.

Kurangnya pustaka inilah yang menyebabkan banyak masyarakat yang malas untuk mempelajari bahasa jawa. Bagi mereka mempelajari bahasa jawa dengan membaca cenderung membosankan.

\subsubsection{Analisis Kebutuhan Sistem}

Analisis kebutuhan sistem bertujuan untuk mengidentifikasi kebutuhan hardware, software dan bahan yang akan digunakan dalam mendukung penelitian serta fitur yang akan dibuat untuk aplikasi Pembelajaran Bahasa Jawa. Analisis ini diperlukan sebagai dasar bagi tahapan perancangan sistem dan untuk mengamati bagaimana sistem akan berjalan. 


\subsubsection{Studi Kepustakaan}

Studi kepustakaan seperti mempelajari buku-buku referensi yang berhubungan dengan Android dan membantu dalam pembuatan Aplikasi Pembelajaran Bahasa Jawa. Selain itu juga mempelajari web-web referensi seputar hal yang sama untuk membantu dalam penyajian informasi yang akan ditampilkan.

\subsubsection{Perangkat Keras}

Adapun perangkat keras yang digunakan untuk mendukung pembuatan dan jalannya aplikasi Pembelajaran Bahasa Jawa sebagai berikut :

1. Handphone smartphone samsung GT-i8262

- $\quad$ Sistem Operasi : Android 4.1.5 (Lolipop)

- $\mathrm{CPU}$ : $832 \mathrm{Mhz}$ processor

- Ruang Penyimpan : 4GB (internal) dan 4 GB (microSD)

- Memory : 1GB DDR SDRAM

2. Kabel data serial port

3. Satu unit Laptop dengan spesifkasi antara lain:

- Prosesor : Intel(R) core(TM) i5-3210M CPU @2.50GHz

- $\quad$ Memori RAM : $8 \mathrm{~Gb}$

- $\quad$ Ruang Penyimpan : 500 Gb SATA

\subsubsection{Perangkat Lunak}

1. JDK (Java Development Kit) dan JRE (Java Runtime Environtment)

2. Sistem Operasi Win 764 bit

3. Eclipse

4. Basis data SQLite

\subsubsection{Spesifikasi Program}

Rancangan sistem sangat diperlukan agar arsitektur sistem dapat memenuhi fungsionalitas yang diinginkan oleh pengguna. Arsitektur Pembelajaran Bahasa Jawa adalah pengguna mengakses database Pembelajaran Bahasa Jawa melalui aplikasi (interface). Pengguna dapat melakukan pencarian data pada aplikasi dan pengguna dapat melakukan input jawaban dengan memasukkan nama terlebih dahulu untuk mendapatkan hasil dari soal yang telah dikerjakan. 


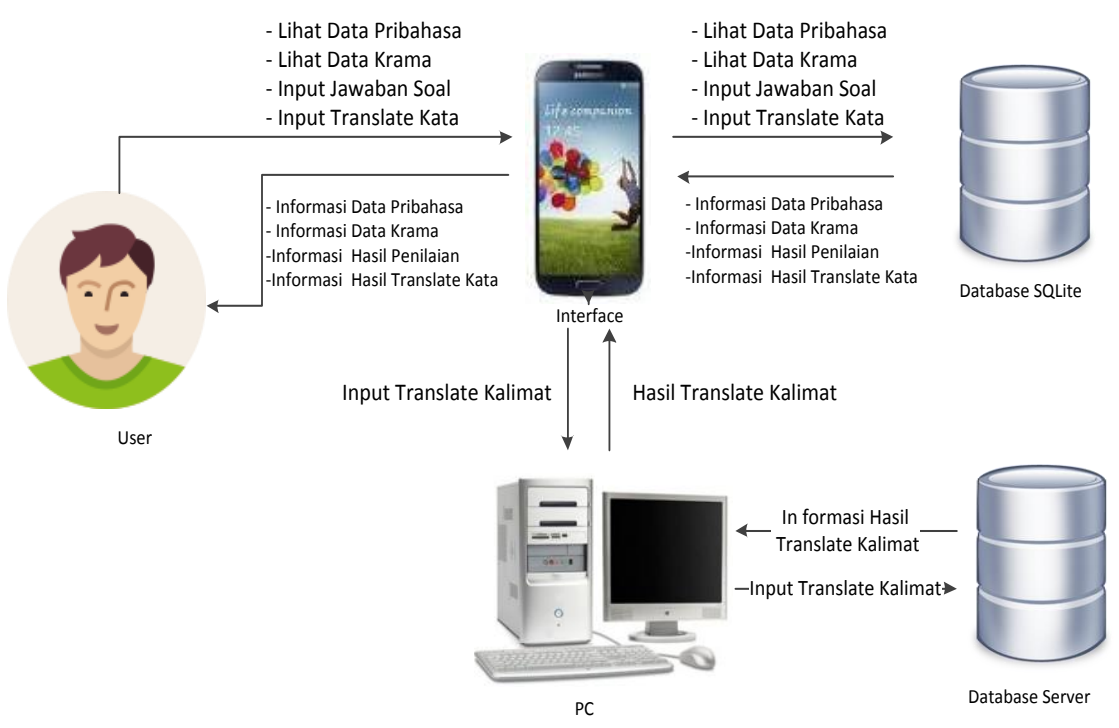

\section{Gambar 3.1. Rancangan Arsitektur}

Pada Gambar 3.1. menjelaskan bahwa penggunaan aplikasi memiliki hubungan antara user dengan smartphone-nya. Hubungan antara smartphone dengan pengguna, pengguna menggunakan perangkat, dan menjalankan aplikasinya untuk mencari data yang ingin dicari atau menjawab soal yang terdapat pada aplikasi. Hubungan antara smartphone dengan database. Dalam database terdapat data-data yang diperlukan oleh aplikasi. Ketika di padukan antara keterangan-keterangan yang ada, yaitu pengguna dapat mencari data pribahasa, data kromo alus dan pengguna juga dapat menginputan jawaban pada soal yang terdapat pada aplikasi. Setiap data yang ingin dicari oleh pengguna akan terhubung dengan database. Nilai yang di dapatkan pengguna dari menjawab soal akan disimpan pada database. Kamus kalimat mengambil data dari database krama yang dihubungkan melalui PC jadi terjemahan kalimat bersifat client server.

\subsection{Rancangan Sistem}

\subsubsection{Flowchart Alur Kerja Aplikasi}

Aliran Informasi mewakili cara dimana data dan control berubah pada saat bergerak melalui sebuah sistem. Program aplikasi ini dibuat berbasis android oleh karena itu aliran informasi-informasi yang ada adalah sebagai berikut : 


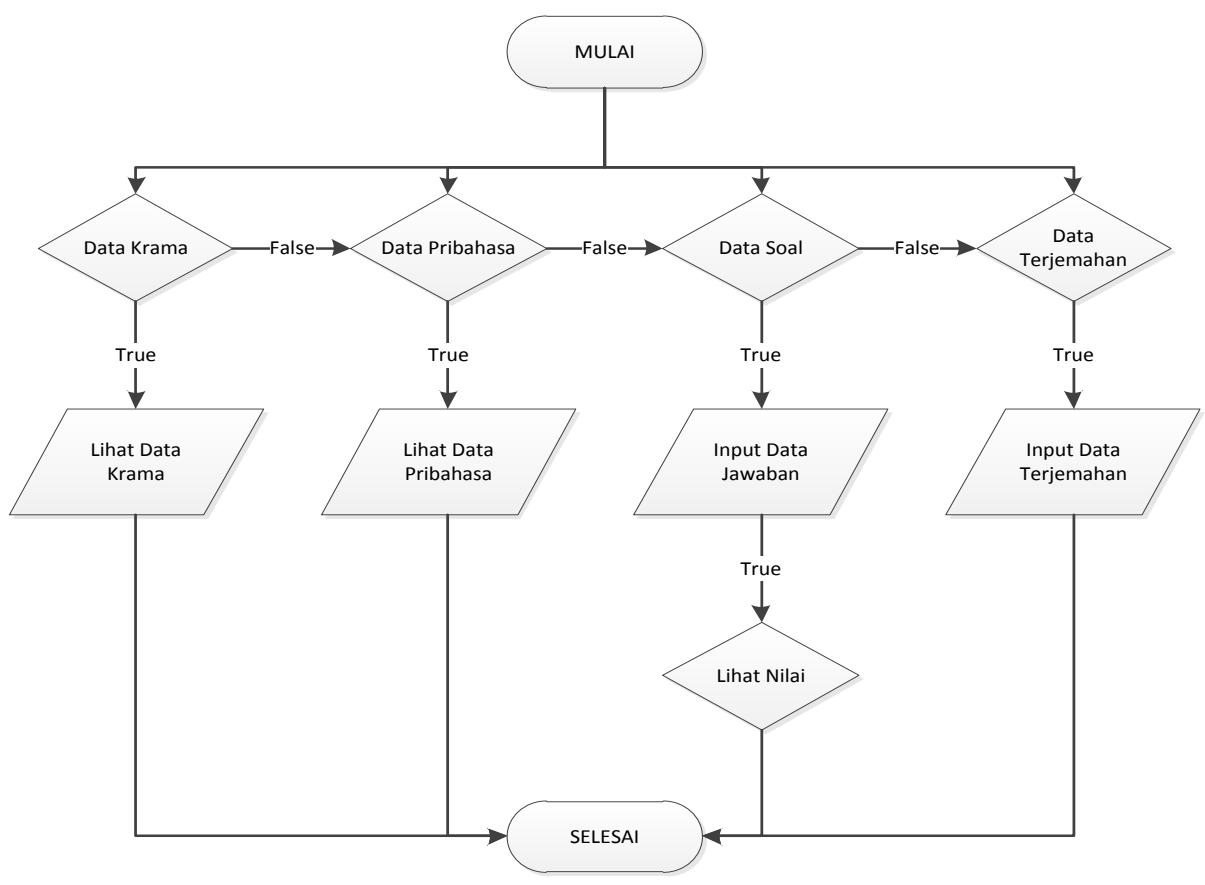

Gambar 3.2. Flowchart Diagram Aplikasi

Gambar 3.2 menjelaskan tentang alur aplikasi setelah aplikasi dijalankan akan terdapat pilihan menu. Pengguna dapat memilih data krama untuk melihat data - data kata dalam tingkatan bahasa krama, data pribahasa melihat kalimat - kalimat dalam pribahasa berserta artinya dalam bahasa jawa, dapat menjawab soal dari menu soal dan dapat melihat nilai setelah menjawab soal, dan dapat juga mencari tingkatan kata dan kalimat krama dalam terjemahan.

\subsubsection{Perancangan Data Flow Diagram (DFD).}

Pada bagian ini akan dijelaskan mengenai aliran data yang terjadi di dalam sistem aplikasi, dengan menggunakan gambaran dalam bentuk Data Flow Diagram (DFD) atau diagram alir data. Perancangan DFD pada penelitian ini mengacu pada buku yang ditulis oleh Pressman, R. S. (2010) dan menggunakan symbol menurut Yourdan dan DeMarco. Tingkat atau level tertinggi DFD adalah level 0 yang menggambarkan proses secara umum. Semakin tinggi level (level 1, level 2, ...dst), maka penjelasan sistem akan semakin detail. 


\subsubsection{Diagram Konteks.}

Diagram konteks merupakan level tertinggi dari DFD yang menggambarkan secara luas tentang seluruh input - output dalam sistem aplikasi Aplikasi Pembelajaran Bahasa Jawa yang dibangun seperti yang digambarkan pada Gambar 3.3.

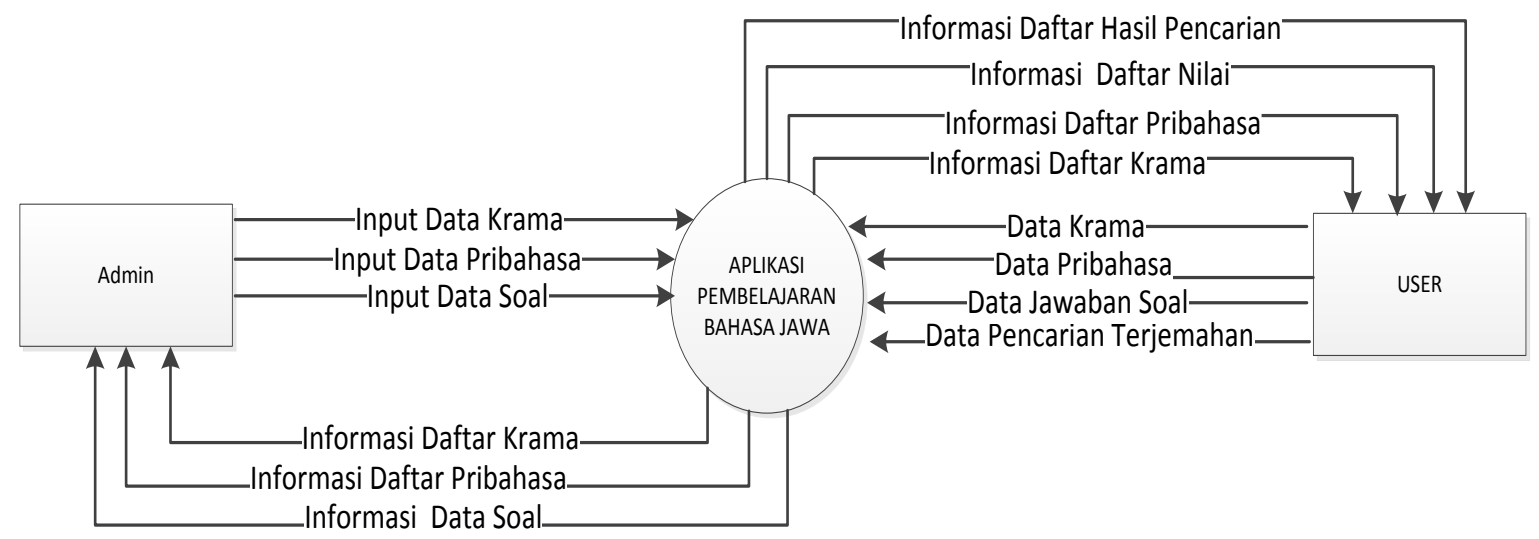

\section{Gambar 3.3. Diagram Konteks}

Gambar 3.3 menjelaskan proses secara umum yang terjadi dalam aplikasi Pembelajaran Bahasa Jawa. Admin memasukkan data krama, data pribahasada data soal ke dalam database sebelum aplikasi selesai di buat. User dapat melihat data krama, data pribahasa, memasukkan jawaban dari soal dan dapat mencari kata dalam kamus. Hasil yang didapatkan oleh user dalam melihat data krama dan data pribahasa adalah data data yang ada terkait dengan krama dan pribahasa. Dalam menjawab soal hasil yang didapatkan oleh pengguna adalah nilai dari hasil jawaban yang telah dimasukkan. Untuk pencarian kata atau kalimat hasil yang didapatkan adalah hasil pencarian kata atau kalimat dalam bahasa jawa maupun bahasa indonesia.

\subsubsection{Diagram level 1}

Diagram level 1 menggambarkan lebih detail proses - proses yang terdapat dalam sistem aplikasi Pembelajaran Bahasa Jawa seperti yang ditunjukkan Gambar 3.4. 


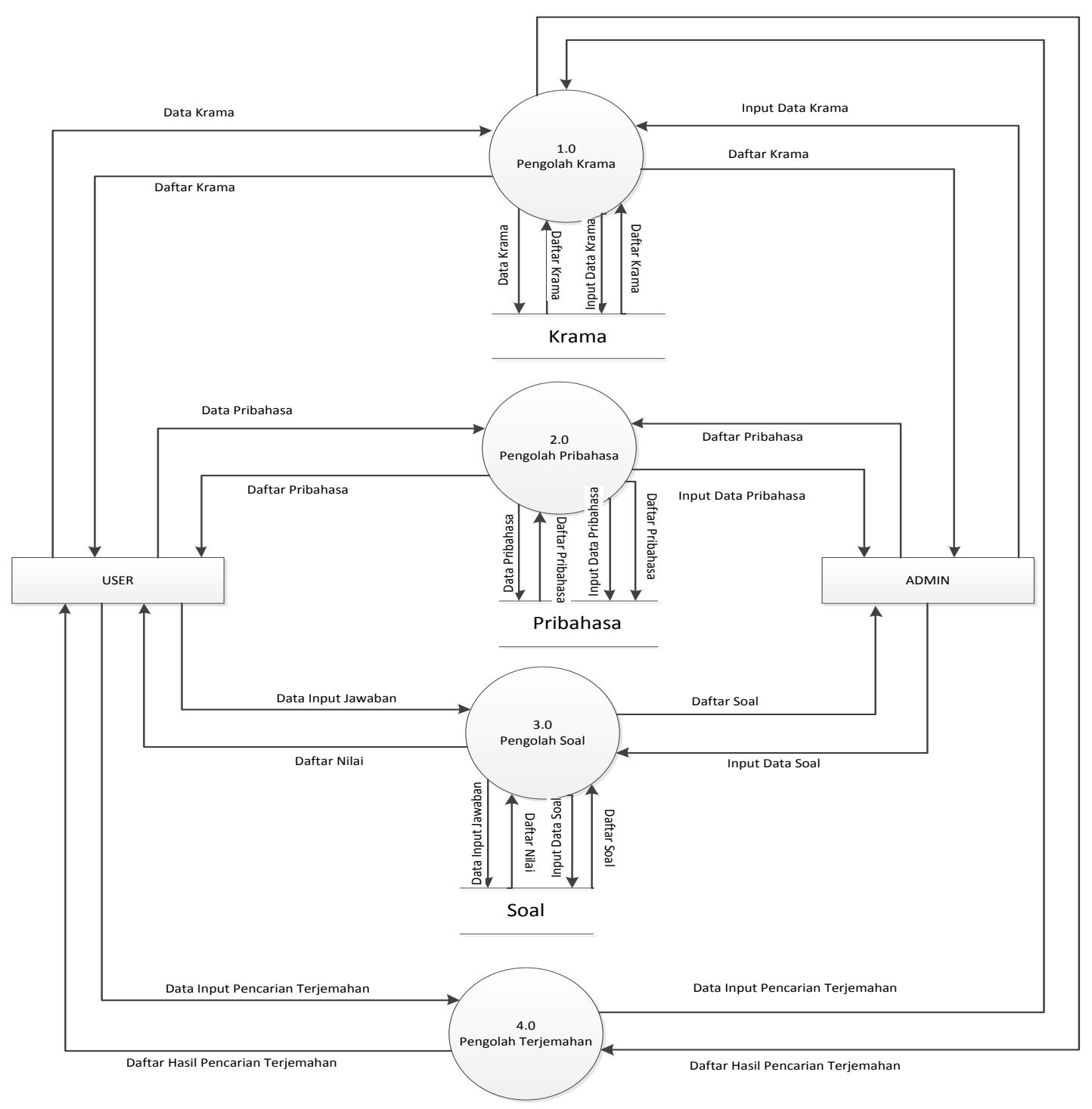

Gambar 3.4. DFD level 1 Aplikasi Pembelajaran Bahasa Jawa

Pada DFD level 1 aplikasi Pembelajaran Bahasa Jawa proses - proses dapat dijelaskan lebih terperinci. Admin dapat memasukkan data krama yang disimpan dalam database krama dan dapat memasukkan data pribahasa yang dapat disimpan pada database pribahasa. Admin juga memasukkan soal-soal yang tersimpan pada database soal. Sedangkan user dapat melihat data krama yang telah tersimpan dalam database krama dan dapat melihat data pribahasa yang telah tersimpan pada database pribahasa. User juga dapat menjawab soal-soal yang ada pada database soal. Jawaban yang telah dimasukkan oleh user juga kan disimpan kedalam database dan user dapat melihat nilai yang didapat dari menjawab soal. Dalam aplikasi user juga dapat memasukkan kata atau 
kalimat pencarian dalam terjemahan yang terdapat pada database krama dan user akan dapat hasil pencarian kata atau kalimat dalam terjemahan yang sedang dicari.

Diagram level 2

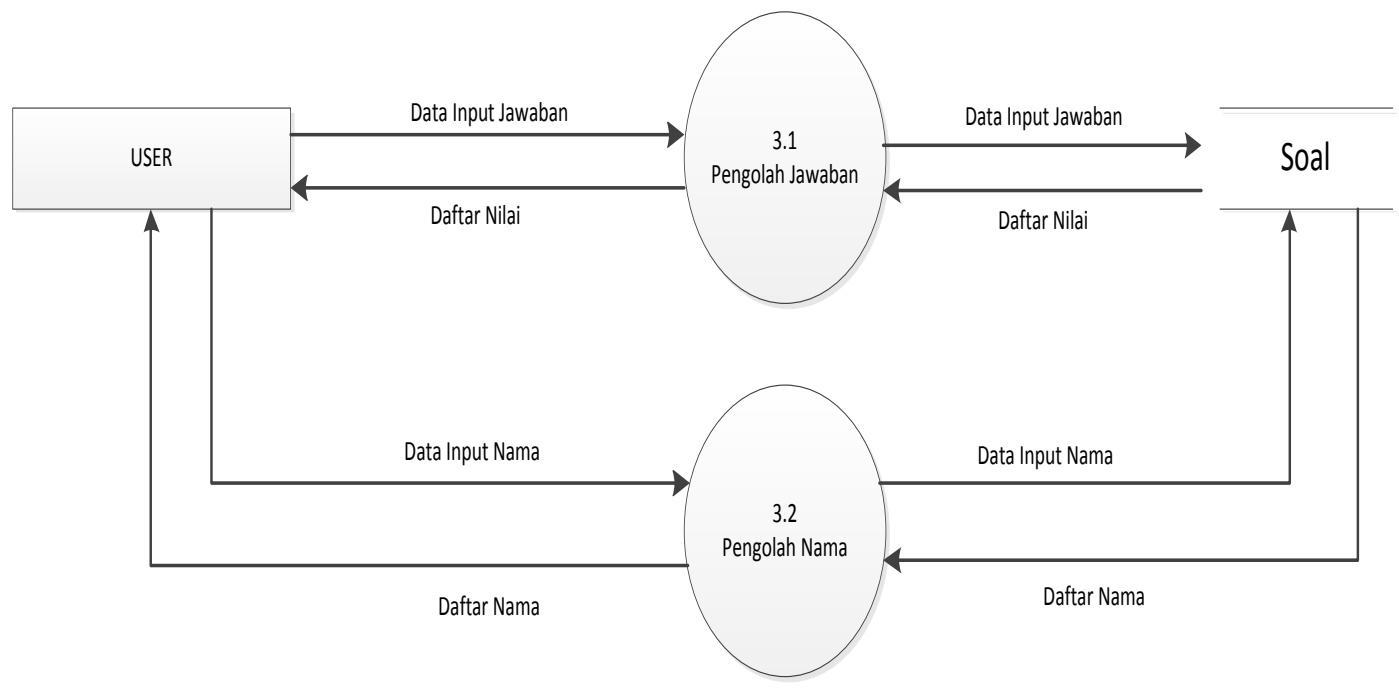

Gambar 3.5. DFD level 2 Data Soal

Pada DFD level 2 merupakan rincian dari DFD level 0 pada bagian soal. Pada DFD Level 2 user dapat memasukkan nama saat hasil soal atau nilai pada soal telah keluar. Input nama yang dilakukan oleh user akan diolah dan disimpan ke dalam database soal kemudian dari database setelah diolah akan diterima user kembali dengan daftar informasi nama dan nilai.

3.2.4 Perancangan Entity Relationship Diagram (ERD)

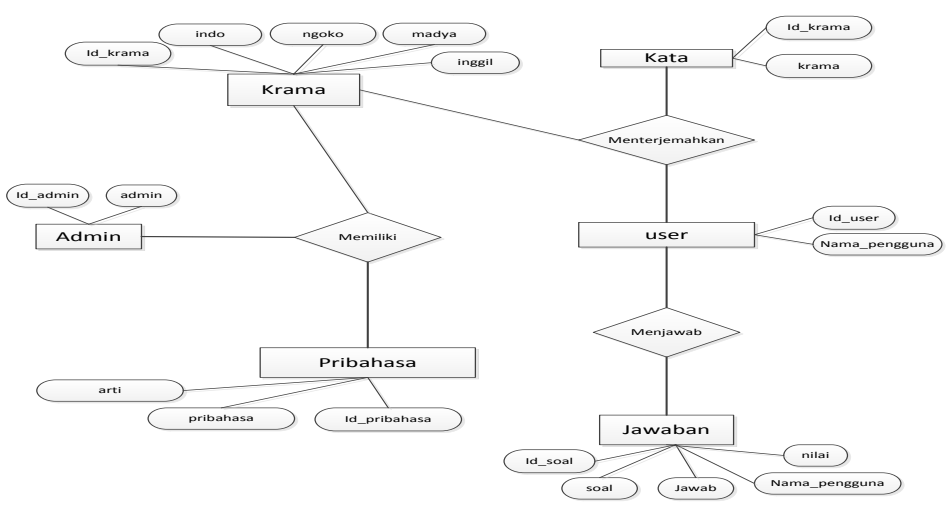

Gambar 3.6. Entity Relationship Diagram

Pada Gambar 3.6 dapat dilihat relasi tabel yang terjadi pada Aplikasi Pembelajaran Bahasa Jawa Berbasis Android. Pada admin dapat memasukkan data bahasa jawa yang 
memiliki tabel krama dan tabel pribahasa yang memiliki atribut masing-masing. Sedangkan pada user dapat menterjemahkan kata maupun kalimat yang diambil pada tabel krama dan dapat menjawab soal yang jawaban dari soal disimpan pada tabel jawaban adapun rancangan basis datanya dapat dilihat berikut ini.

\subsection{Rancangan Basis Data}

Setiap aplikasi memiliki tempat penyimpanan yang digunakan untuk menyimpan data ataupun menyimpan konfigurasi tertentu dari aplikasi. Perancangan Database untuk aplikasi Pembelajaran Bahasa Jawa pada perangkat bergerak Android, menggunakan sistem basis data dari SQL Lite. Adapun struktur tabelnya ada dibawah ini:

\subsubsection{Struktur Tabel}

Struktur tabel dibentuk beserta nama dan tipe datanya. Berikut adalah struktur tabel yang ada pada aplikasi Pembelajaran Bahasa Jawa.

\section{Tabel Krama}

Pada tabel Krama diwakili oleh entitas tabel krama. Tabel Krama digunakan untuk menyimpan semua data krama. Dalam tabel ini terdapat 5 field yang terdiri dari id_krama, indo, ngoko, madya dan inggil. Struktur tabel krama seperti pada Tabel 3.1 berikut :

\section{Tabel 3.1. Tabel krama}

\begin{tabular}{|l|l|l|}
\hline \multicolumn{1}{|c|}{ Field } & \multicolumn{1}{c|}{ Tipe data } & \multicolumn{1}{c|}{ Keterangan } \\
\hline Id_krama & Int (2) primary key & Auto increment \\
\hline indo & Text not null & $\begin{array}{l}\text { Menyimpan arti krama bahasa } \\
\text { indonesia }\end{array}$ \\
\hline ngoko & Text not null & Menyimpan data krama ngoko \\
\hline madya & Text not null & Menyimpan data krama madya \\
\hline inggil & Text not null & Menyimpan data krama inggil \\
\hline
\end{tabular}

\section{Tabel Pribahasa}

Pada tabel Pribahasa diwakili oleh entitas tabel pribahasa. Tabel pribahasa digunakan untuk menyimpan data pribahasa. Dalam tabel pribahasa terdapat 3 field yang terdiri dari id_pribahasa, jawa dan arti. Struktur tabel pribahasa seperti pada Tabel 3.2. 
Tabel 3.2 Tabel pribahasa

\begin{tabular}{|c|c|c|}
\hline Field & Tipe data & Keterangan \\
\hline id_pribahasa & $\begin{array}{c}\text { int (2) not null } \\
\text { primary key }\end{array}$ & Auto increment \\
\hline Jawa & text not null & Menyimpan data pribahasa \\
\hline Arti & text not null & Menyimpan data arti dari pribahasa \\
\hline
\end{tabular}

\section{Tabel Soal Krama}

Pada tabel Soal Krama diwakili oleh entitas tabel soal_krama. Tabel Soal Krama digunakan untuk menyimpan data-data soal krama. Dalam tabel soal krama terdapat 7 field yang terdiri dari id_soal, isi_soal, jawaban_a, jawaban_b, jawaban_c, jawaban_d dan jawbaan_benar. Struktur tabel soal krama seperti pada Tabel 3.3 berikut :

Tabel 3.3 Tabel soal_krama

\begin{tabular}{|l|l|l|}
\hline \multicolumn{1}{|c|}{ Field } & \multicolumn{1}{|c|}{ Tipe data } & \multicolumn{1}{c|}{ Keterangan } \\
\hline id_soal & $\begin{array}{l}\text { int (2) not null } \\
\text { primary key }\end{array}$ & Auto increment \\
\hline Isi_soal & text not null & Menyimpan data soal krama \\
\hline Jawaban_a & varchar not null & Menyimpan data jawaban A \\
\hline Jawaban_b & varchar not null & Menyimpan data jawaban B \\
\hline Jawaban_c & varchar not null & Menyimpan data jawaban C \\
\hline Jawaban_d & varchar not null & Menyimpan data jawaban D \\
\hline Jawaban_benar & varchar not null & Menyimpan data jawaban benar \\
\hline
\end{tabular}

4. Tabel Soal Pribahasa

Pada tabel Soal Pribahasa diwakili oleh entitas tabel soal_pribahasa. Tabel Soal Pribahasa digunakan untuk menyimpan data-data soal Pribahasa. Dalam tabel soal Pribahasa terdapat 7 field yang terdiri dari id_soal, isi_soal, jawaban_a, jawaban_b, jawaban_c, jawaban_d dan jawaban_benar. Struktur tabel soal pribahasa seperti pada Tabel 3.4 berikut : 
Tabel 3.4 Tabel soal_pribahasa

\begin{tabular}{|l|l|l|}
\hline \multicolumn{1}{|c|}{ Field } & \multicolumn{1}{|c|}{ Tipe data } & \multicolumn{1}{c|}{ Keterangan } \\
\hline id_soal & $\begin{array}{l}\text { int (2) not null } \\
\text { primary key }\end{array}$ & Auto increment \\
\hline Isi_soal & text not null & Menyimpan data soal pribahasa \\
\hline Jawaban_a & text not null & Menyimpan data jawaban A \\
\hline Jawaban_b & text not null & Menyimpan data jawaban B \\
\hline Jawaban_c & text not null & Menyimpan data jawaban C \\
\hline Jawaban_d & text not null & Menyimpan data jawaban D \\
\hline Jawaban_benar & text not null & Menyimpan data jawaban benar \\
\hline
\end{tabular}

\section{Tabel Soal Campuran}

Pada tabel Soal Campuran diwakili oleh entitas tabel soal_campuran. Tabel Soal campuran digunakan untuk menyimpan data-data soal campuran. Isi dari soal campuran adalah perpaduan antara soal krama dan soal pribahasa. Dalam tabel soal Pribahasa terdapat 7 field yang terdiri dari id_soal, isi_soal, jawaban_a, jawaban_b, jawaban_c, jawaban_d dan jawaban_benar. Struktur tabel soal campuran seperti pada Tabel 3.5 berikut :

Tabel 3.5 Tabel soal_campuran

\begin{tabular}{|c|c|c|}
\hline Field & Tipe data & Keterangan \\
\hline id_soal & $\begin{array}{c}\text { int (2) not null } \\
\text { primary key }\end{array}$ & Auto increment \\
\hline Isi_soal & text not null & Menyimpan data soal campuran \\
\hline Jawaban_a & text not null & Menyimpan data jawaban A \\
\hline Jawaban_b & text not null & Menyimpan data jawaban B \\
\hline Jawaban_c & text not null & Menyimpan data jawaban C \\
\hline Jawaban_d & text not null & Menyimpan data jawaban D \\
\hline Jawaban_benar & text not null & Menyimpan data jawaban benar \\
\hline
\end{tabular}

\section{Tabel Nilai Krama}

Pada tabel Nilai Krama diwakili oleh entitas tabel nilaiKrama. Tabel nilai krama digunakan untuk menyimpan data-data nilai dari soal krama yang telah dikerjakan. Dalam tabel nilai krama terdapat 3 field yang terdiri dari id_pengguna, nama_pengguna dan nilai_pengguna. Struktur tabel nilai krama seperti pada Tabel 3.6. berikut : 
Tabel 3.6 Tabel nilai Krama

\begin{tabular}{|c|c|cc|}
\hline Field & Tipe data & \multicolumn{2}{|c|}{ Keterangan } \\
\hline id_pengguna & $\begin{array}{r}\text { int }(2) \text { not null } \\
\text { primary key }\end{array}$ & Auto increment & \\
\hline Nama_pengguna & varchar not null & $\begin{array}{c}\text { Menyimpan data nama } \\
\text { pengguna }\end{array}$ \\
\hline Nilai_pengguna & varchar not null & Menyimpan data nilai pengguna \\
\hline
\end{tabular}

7. Tabel Nilai Pribahasa

Pada tabel Nilai Pribahasa diwakili oleh entitas tabel nilaiPribahasa. Tabel nilai pribahasa digunakan untuk menyimpan data-data nilai dari soal pribahasa yang telah dikerjakan. Dalam tabel nilai pribahasa terdapat 3 field yang terdiri dari id_pengguna, nama_pengguna dan nilai_pengguna. Struktur tabel nilai pribahasa seperti pada Tabel 3.7 berikut :

Tabel 3.7 Tabel nilai Pribahasa

\begin{tabular}{|c|c|c|}
\hline Field & Tipe data & Keterangan \\
\hline id_pengguna & $\begin{array}{c}\text { int (2) not null } \\
\text { primary key }\end{array}$ & Auto increment \\
\hline Nama_pengguna & varchar not null & Menyimpan data nama pengguna \\
\hline Nilai_pengguna & varchar not null & Menyimpan data nilai pengguna \\
\hline
\end{tabular}

8. Tabel Nilai Campuran

Pada tabel Nilai Campuran diwakili oleh entitas tabel nilaiCampuran. Tabel nilai campuran digunakan untuk menyimpan data-data nilai dari soal campuran yang telah dikerjakan. Dalam tabel nilai campuran terdapat 3 field yang terdiri dari id_pengguna, nama_pengguna dan nilai_pengguna. Struktur tabel nilai campuran seperti pada Tabel 3.8 berikut :

Tabel 3.8 Tabel nilai Campuran

\begin{tabular}{|c|c|c|}
\hline Field & Tipe data & Keterangan \\
\hline id_pengguna & $\begin{array}{c}\text { int (2) not null } \\
\text { primary key }\end{array}$ & Auto increment \\
\hline Nama_pengguna & varchar not null & Menyimpan data nama pengguna \\
\hline Nilai_pengguna & varchar not null & Menyimpan data nilai pengguna \\
\hline
\end{tabular}




\section{Tabel Jawaban Krama}

Pada tabel Jawaban Krama diwakili oleh entitas tabel jawabanKrama. Tabel jawaban krama digunakan untuk menyimpan data-data jawaban dari soal krama yang telah dikerjakan. Dalam tabel jawaban krama terdapat 4 field yang terdiri dari id_jawaban, isi_soal1, jawaban_benar1 dan jawaban_pilihan. Struktur tabel jawaban krama seperti pada Tabel 3.9 berikut :

Tabel 3.9 Tabel jawaban Krama

\begin{tabular}{|c|c|c|}
\hline Field & Tipe data & Keterangan \\
\hline id_jawaban & $\begin{array}{c}\text { int (2) not null } \\
\text { primary key }\end{array}$ & Auto increment \\
\hline Isi_soal1 & text not null & Menyimpan data soal \\
\hline Jawaban_benar1 & varchar not null & Menyimpan data jawaban benar \\
\hline Jawaban_pilihan & varchar not null & Menyimpan data pilihan jawaban \\
\hline
\end{tabular}

10. Tabel Jawaban Pribahasa

Pada tabel Jawaban Pribahasa diwakili oleh entitas tabel jawabanPribahasa. Tabel jawaban pribahasa digunakan untuk menyimpan data-data jawaban dari soal pribahasa yang telah dikerjakan. Dalam tabel jawaban pribahasa terdapat 4 field yang terdiri dari id_jawaban, isi_soal1, jawaban_benar1 dan jawaban_pilihan. Struktur tabel jawaban pribahasa seperti pada Tabel 3.10 berikut :

Tabel 3.10 Tabel jawaban Pribahasa

\begin{tabular}{|c|c|c|}
\hline Field & Tipe data & Keterangan \\
\hline id_jawaban & $\begin{array}{c}\text { int (2) not null } \\
\text { primary key }\end{array}$ & Auto increment \\
\hline Isi_soal1 & text not null & Menyimpan data soal \\
\hline Jawaban_benar1 & varchar not null & Menyimpan data jawaban benar \\
\hline Jawaban_pilihan & varchar not null & Menyimpan data pilihan jawaban \\
\hline
\end{tabular}

11. Tabel Jawaban Campuran

Pada tabel Jawaban Campuran diwakili oleh entitas tabel jawabanCampuran. Tabel jawaban campuran digunakan untuk menyimpan data-data jawaban dari soal campuran yang telah dikerjakan. Dalam tabel jawaban campuran terdapat 4 field yang terdiri dari id_jawaban, isi_soal1, jawaban_benar1 dan jawaban_pilihan. Struktur tabel jawaban campuran seperti pada Tabel 3.11 berikut : 
Tabel 3.11 Tabel jawaban Campuran

\begin{tabular}{|c|c|c|}
\hline Field & Tipe data & Keterangan \\
\hline id_jawaban & $\begin{array}{c}\text { int (2) not null } \\
\text { primary key }\end{array}$ & Auto increment \\
\hline Isi_soal1 & text not null & Menyimpan data soal \\
\hline Jawaban_benar1 & varchar not null & Menyimpan data jawaban benar \\
\hline Jawaban_pilihan & varchar not null & Menyimpan data pilihan jawaban \\
\hline
\end{tabular}

\subsection{Rancangan Desain Antarmuka Pengguna}

Setelah perancangan sistem yang menjelaskan bagaimana sistem akan berjalan, selanjutnya merancang tampilan antarmuka untuk user. Perancangan antarmuka adalah sketsa desain aplikasi yang akan dibuat. Perancangan antarmuka dibuat untuk memudahkan dalam pembuatan tampilan aplikasi.

\subsubsection{Perancangan Antarmuka}

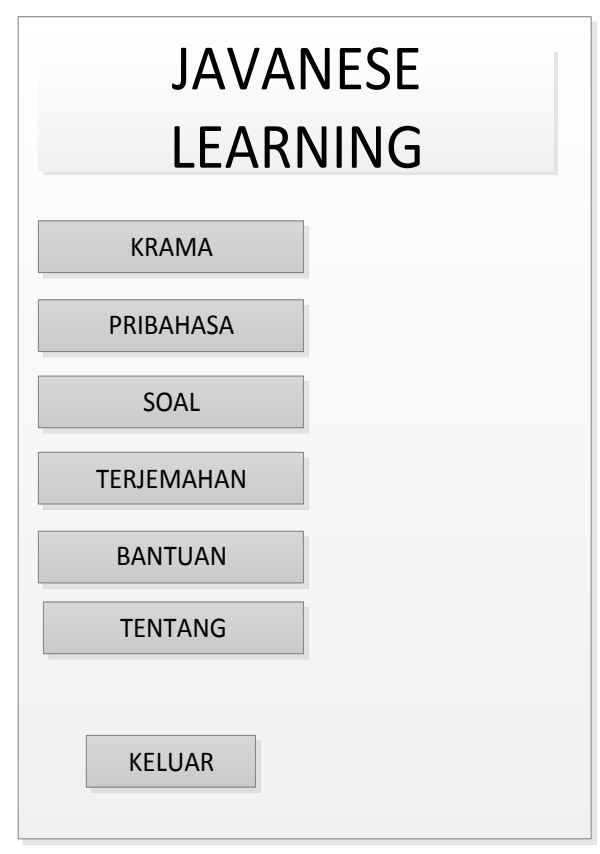

Gambar 3.7 Tampilan awal Aplikasi Pembelajaran Bahasa Jawa

Keterangan :

1. Menu kata-kata krama

2. Menu kata-kata pribahasa

3. Menu soal bahasa jawa

4. Menu kamus bahasa jawa 
5. Bantuan

6. Tentang

7. Keluar

Desain pada Gambar 3.7 terdapat 7 menu. Ada 4 menu yang dapat digunakan dan dipilih. Gambar 3.7 merupakan tampilan utama ketika aplikasi dibuka.

\subsubsection{Perancangan Antarmuka Halaman Menu Krama}

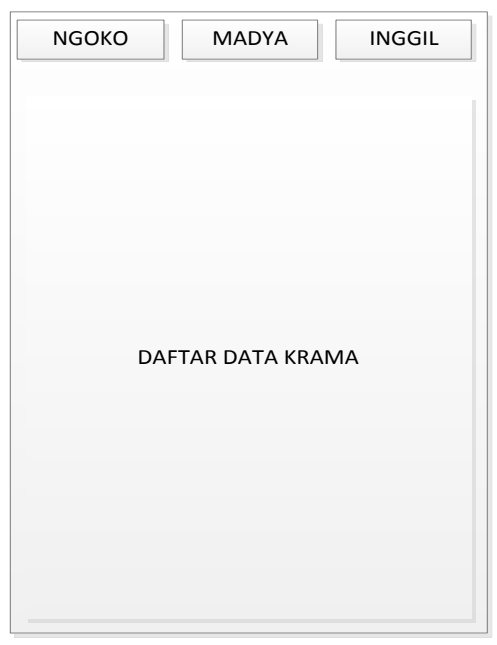

\section{Gambar 3.8. Tampilan halaman menu krama}

Desain pada Gambar 3.8 merupakan halaman dari menu krama yang muncul setelah memilih menu kata-kata krama. Pada Gambar 3.8 dapat dijelaskan akan ada data-data mengenai kata-kata dalam tingkatan bahasa krama.

\subsubsection{Perancangan Halaman Menu Pribahasa}

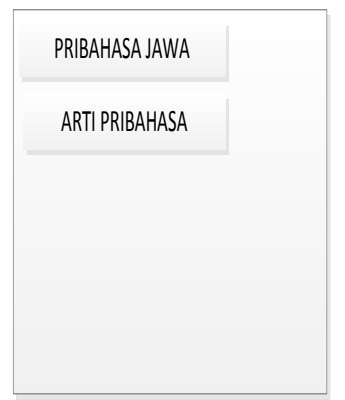

Gambar 3.9 Tampilan halaman menu pribahasa

Desain pada Gambar 3.9 merupakan halaman dari menu pribahasa yang muncul setelah memilih menu kata-kata pribahasa. Pada gambar 3.9 dapat dilihat akan ada data- 
data tentang kalimat pribahasa dalam bahasa jawa. Untuk yang atas adalah pribahasanya dan untuk yang bawah adalah arti pribahasa.

\subsubsection{Perancangan Halaman Menu Jenis Soal}

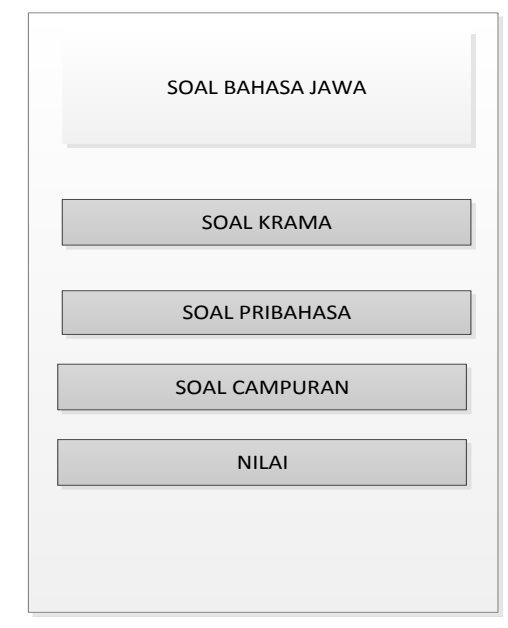

Gambar 3.10 Tampilan halaman menu jenis soal

Desain pada Gambar 3.10 merupakan halaman jenis menu dari soal bahasa jawa yang telah dipilih, pada menu halaman soal akan ada pilihan menu lagi untuk memilih jenis soal yang ingin dikerjakan. Pada Gambar 3.10 dapat dilihat terdapat 3 jenis soal dan 1 menu nilai yang digunakan untuk melihat daftar nilai.

\subsubsection{Perancangan Halaman Menu Soal}

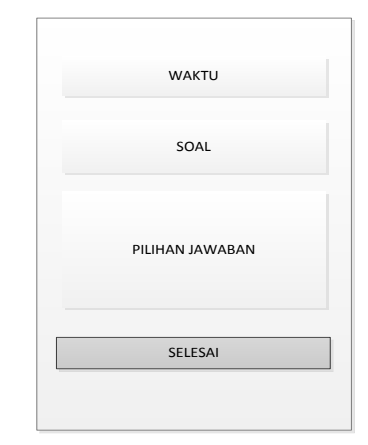

Gambar 3.11 Tampilan halaman menu soal 
Keterangan :

1. Tampilan waktu

2. Tampilan soal

3. Tampilan pilihan jawaban

4. Tombol lanjut / selesai

Desain pada Gambar 3.11 merupakan halaman soal dari menu jenis soal. Pada Gambar 3.11 dapat dilihat terdapat 3 bagian dalam halaman soal. Ada tampilan waktu, tampilan soal dan tampilan pilihan jawaban. Pada menu ini bila telah mengerjakan ditekan tombol lanjut sampai tombol selesai yang menandakan soal telah selesai.

\subsubsection{Perancangan Halaman Soal Selesai}

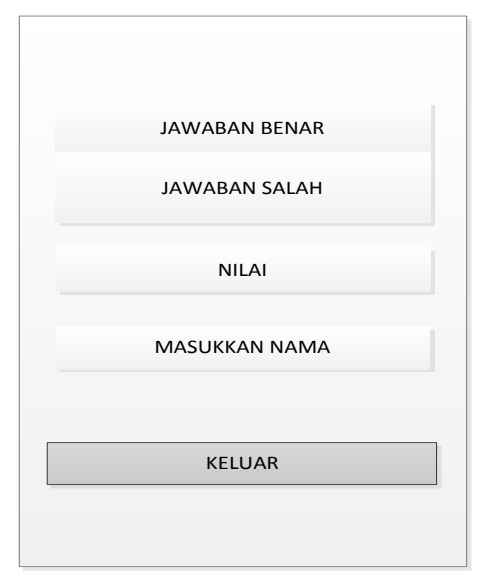

\section{Gambar 3.12 Tampilan halaman soal selesai}

Desain pada Gambar 3.12 merupakan tampilan helaman soal selesai. Setelah selesai menjawab soal maka akan muncul jawaban benar, jawaban salah, nilai dan memasukkan nama kemudian data akan disimpan.

\subsubsection{Perancangan Halaman Nilai}

Desain pada Gambar 3.13 merupakan halaman nilai. Pada halaman nilai dapat dilihat daftar nama dan nilai dari pengguna yang menegrjakan soal. 


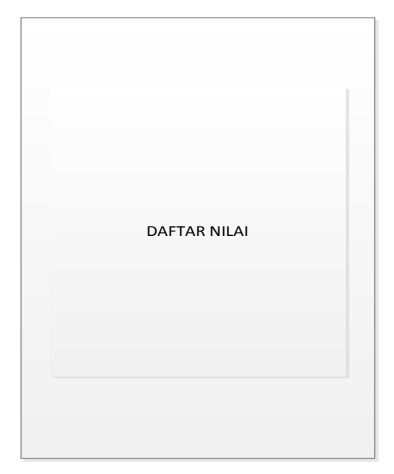

Gambar 3.13 Tampilan halaman nilai

\subsubsection{Perancangan Halaman Pilihan Kamus.}

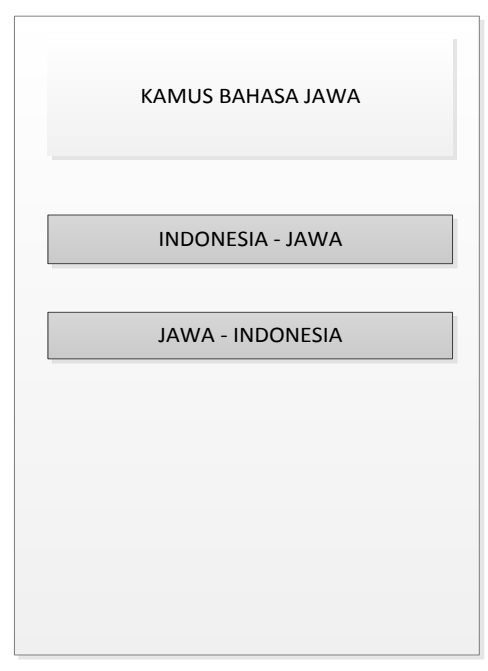

Gambar 3.14 Tampilan halaman pilihan kamus

Keterangan :

1. Menu indonesia - jawa

2. Menu jawa - indonesia

Desain pada Gambar 3.14 merupakan halaman pilihan menu kamus. Pada halaman pilihan menu kamus terdapat dua pilihan jenis kamus. 


\subsubsection{Perancangan Halaman Menu Kamus}
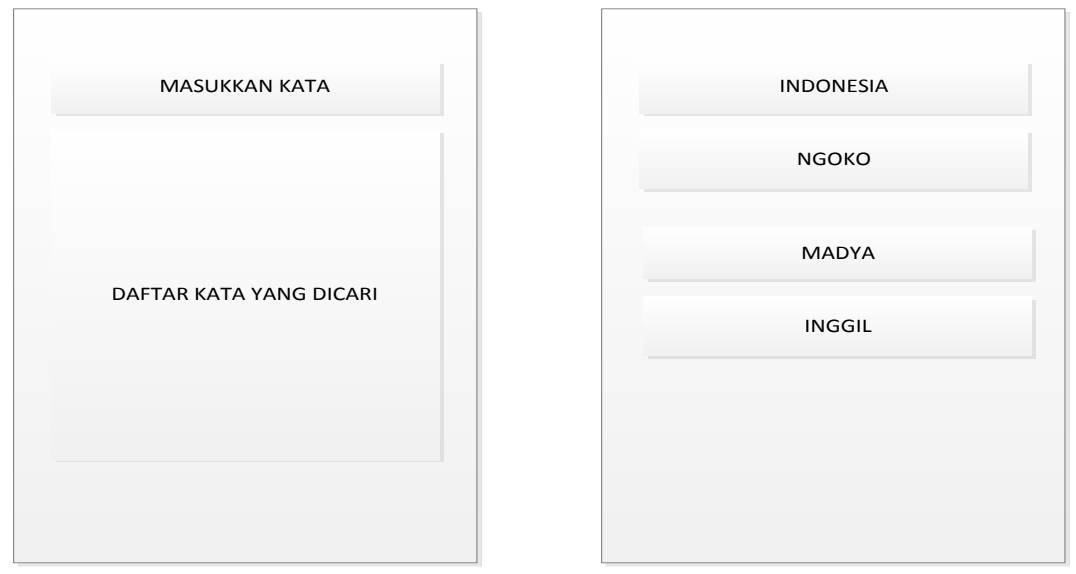

\section{Gambar 3.15 Tampilan halaman menu kamus}

Keterangan :

1. Edit text masukkan kata

2. List view kata yang dicari

3. Data dari kata yang dicari

Desain pada Gambar 3.15 merupakan halaman menu kamus. Pada halaman ini dapat dilihat setelah kata dimasukkan akan muncul pilihan kata yang dicari berupa list view, dan ketika list di pilih akan masuk pada tampilan yang menampilkan data-data dari kata yang dicari.

\subsubsection{Perancangan Halaman Menu Tentang}

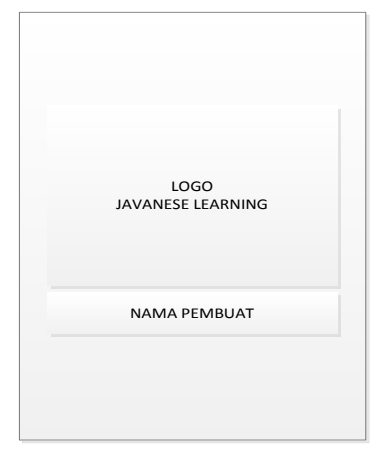

Gambar 3.16 Tampilan halaman menu tentang 
Desain pada Gambar 3.16 merupakan halaman menu tentang. Pada halaman ini terdapat logo dan nama pembuat aplikasi.

\section{HASIL DAN PEMBAHASAN}

Implementasi merupakan tahap pengembangan rancangan menjadi kode program. Bagian utama implementasi adalah penjabaran dari rancangan aplikasi yang sudah dibuat menjadi menjadi sebuah aplikasi Android yang diimplementasikan dalam kode program atau syntax Bahasa Pemrograman Java.

\subsection{Antarmuka Pengguna}

Halaman utama merupakan antarmuka user yang merupakan inti dari aplikasi. Pada halaman utama terdapat 7 menu yang dapat digunakan.

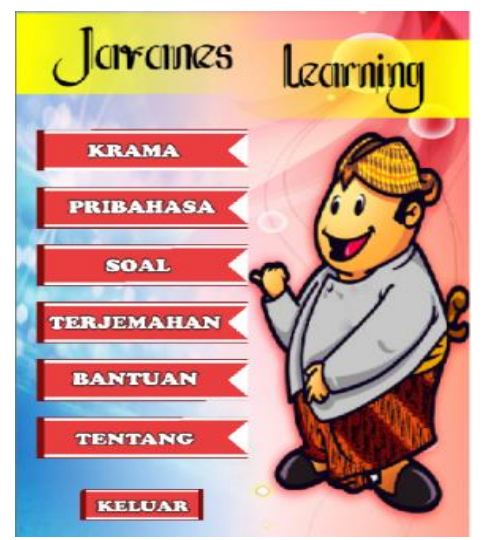

\section{Gambar 4.1. Tampilan Halaman Utama}

Gambar 4.1 menunjukkan bahwa halaman utama terdapat 7 menu yang dapat dipilih. Setiap menu memiliki fungsi masing-masing.

\subsection{Halaman Krama}

Halaman krama merupakan halaman yang digunakan untuk menampilkan data krama yang ada pada database. Pada halaman krama hanya menampilkan semua data krama dan artinya dalam bahasa indonesia. Tampilan pada data krama terdapat scroll yang dapat diarahkan kebawah untuk melihat data krama secara keseluruhan. 


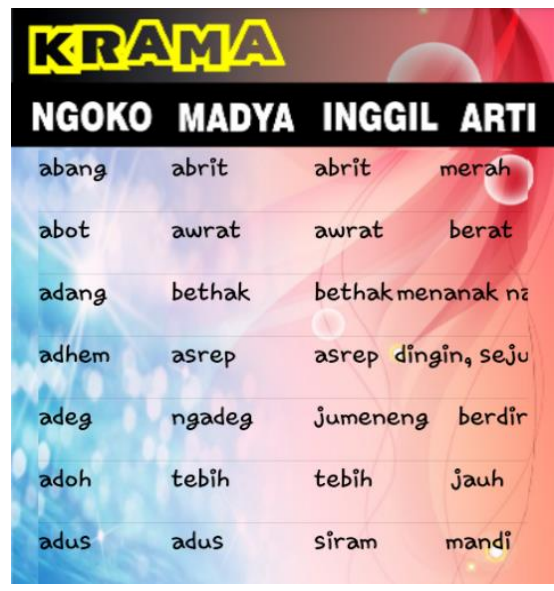

Gambar 4.2 Tampilan Halaman Krama

Gambar 4.2 meunjukkan semua data krama yang ada pada database. Semua data krama yang ada akan ditampilkan dan untuk melihat semua data krama scroll kebawah pada tampilan

\subsection{Halaman Soal}

Halaman soal merupakan pilihan jenis soal yang akan dierjakan. Terdapat tiga jenis soal yang dapat dipilih. Ada soal krama, soal pribahasa dan soal campuran. Pada menu soal ini juga terdapat tombol nilai yang digunakan untuk melihat nilai yang diperoleh dari mengerjakan soal. Berikut adalah tampilah halaman soal.

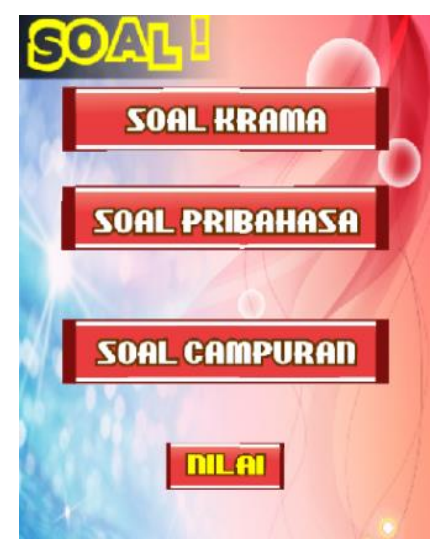

Gambar 4.3 Tampilan Halaman Soal 
Gambar 4.3 menunjukkan semua menu yang dapat dipilih pada menu soal. Terdapat tiga jenis pilihan soal yang dapat dipilih. Ada soal krama, soal pribahasa dan soal campuran. Pada menu soal ini juga terdapat satu menu nilai.

\subsection{Halaman Terjemahan}

Halaman terjemahan merupakan menu halaman yang memiliki dua menu. Pada halaman terjemahan digunakan untuk menterjemahkan kata atau kalimat. Pada terjemahan kata akan terdapat list kata yang diinginkan. Pada kalimat akan menampilkan terjemahan dalam tiga tingkat krama.

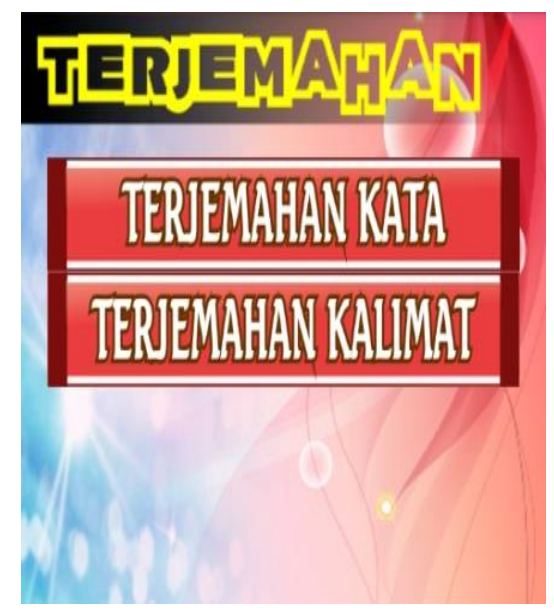

\section{Gambar 4.4. Tampilan Terjemahan}

Gambar 4.4 meunjukkan semua menu yang ada pada terjemahan. Pada menu terjemahan terdapat dua pilihan menu untuk terjemahan kata dan terjemahan kalimat.

\subsection{Halaman Terjemahan Kata}

Halaman terjemahan kata merupakan tempat untuk mencari dan menerjemahkan kata. Pada menu ini pengguna memasukkan huruf atau kata yang ingin diterjemahkan. 


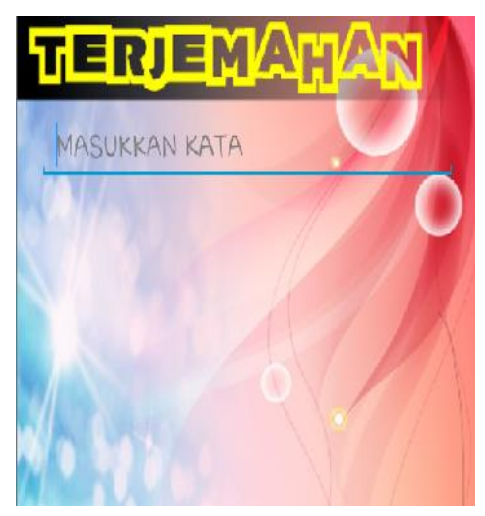

\section{Gambar 4.5. Tampilan Terjemahan Kata}

Gambar 4.5 menunjukkan tampilan dari tempat untuk mencari atau memasukkan kata yang akan diterjemahkan. Terjemahan kata dilakukan hanya dalam satu halaman. Terjemahan yang terjadi bersifat menterjemahkan kata dalam tiga tingkat bahasa krama dalam bahasa jawa.

\subsection{Halaman Terjemahan Kalimat}

Halaman terjemahan kalimat merupakan tempat untuk menerjemahkan kalimat dalam bahasa indonesia ke bahasa jawa atau dalam bahasa jawa ke bahasa indonesia

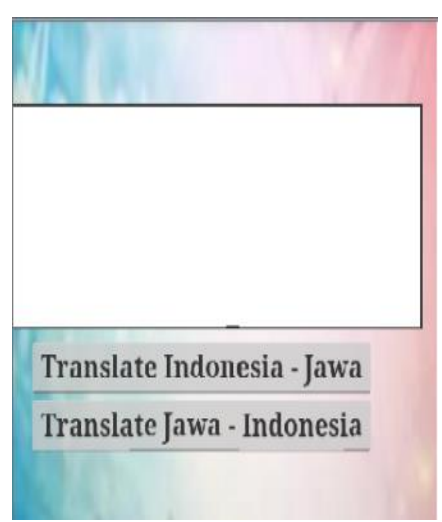

\section{Gambar 4.6. Tampilan Terjemahan Kalimat}

Gambar 4.6. menunjukkan tampilan dari tempat untuk mencari atau memasukkan kata yang akan diterjemahkan. Terjemahan kata dilakukan hanya dalam satu halaman. Terjemahan yang terjadi bersifat menerjemahkan kata dalam tiga tingkat bahasa krama dalam bahasa jawa. 


\section{KESIMPULAN DAN SARAN}

\subsection{Kesimpulan}

Dari implementasi dan pembahasan yang sudah dilakukan, maka dapat diambil beberapa kesimpulan sebagai berikut :

1. Telah terwujudnya aplikasi yang bisa membantu dalam pembelajaran bahasa jawa dan dalam terjemahan bahasa jawa - indonesia atau sebaliknya.

2. Aplikasi dapat menyimpan nama dan nilai pengguna yang menjawab soal.

3. Aplikasi dapat menampilkan data krama dan data pribahasa.

\subsection{Saran}

Dengan keterbatasan kemampuan dan waktu yang tersedia untuk pengembangan aplikasi agar lebih baik lagi, maka dari hasil implementasi yang sudah dilakukan, disarankan beberapa hal sebagai berikut :

1. Sebaiknya pada terjemahan kalimat tidak bersifat server karena terkendala jaringan.

2. Pada soal sebaiknya bersifat naik level dalam pengerjaanya dan jawaban yang tersedia acak setiap mengerjakan.

\section{DAFTAR PUSTAKA}

[1] Edi., P., (2014). Pembelajaran Kaidah Bahasa Jawa Berbasis Andorid Mobile. S1 Teknik Informatika. Surakarta: Universitas Muhammadiyah Surakarta.

[2] Hermawan., S., (2011). Mudah membuat aplikasi Android. Yogyakarta: Andi Offset.

[3] Intan N., F., (2014). Aplikasi Kamus Indonesia-Jawa berbasis. S1 Teknik Informatika. Kediri: Universitas Nusantara PGRI Kediri.

[4] Indrajani., (2015)., Database Design (Case Study All in One). Jakarta: PT Elex Media Komputindo.

[5] Kurniawan., (2013). Kamus Aneka Bahasa Daerah Berbasis Android. S1 Teknik Informatika. Surakarta: Universitas Muhammadiyah Surakarta.

[6] Mulyadi., T.,(2010). Membuat aplikasi Android. Yogyakarta: Multimedia Center Publishing. 
[7] Pressman., R., S., (2015). Rekayasa Perangkat Lunak: Pendekatan Praktisi Buku I. Yogyakarta: Andi

[8] Purwadi., M., \& nuning,, Z., (2012), Tata bahasa jawa. Yogyakarta: pura pustaka.

[9] Sadiman, S., A., Rahardjo., Haryono., A., \& Raharjito., (2011). Media Pendidikan, Pengertian, Pengembangan, dan Pemanfaatannya. Jakarta: PT Raja Grafindo Persada.

[10] Safaat, N. (2012). Pemrograman Aplikasi Mobile Samrtphone dan tablet PC Berbasis Mobile. Bandung : Informatika.

[11] Sukamto., \& Salahuddin., (2014)., Rekayasa Perangkat Lunak Terstruktur dan Berorientasi Objek. Bandung: Informatika.

[12] Tofani, M. A. \& Nugraha, G.S. .(2010). Buku Pinter Kawruh Basa Jawi Pepak. Surabaya : Pustaka Agung Harapan. 